\title{
Iskustva mladih obiteljskih poljoprivrednih gospodarstvenika (OPG-ovaca) u Bjelovarsko- bilogorskoj i Požeško-slavonskoj županiji
}

\author{
Helena Pupak \\ Sveučilište u Zagrebu, Filozofski fakultet, Odsjek za sociologiju, Hrvatska \\ e-mail: helenapupak@gmail.com
}

\section{Tijana Trako Poljak Sveučilište u Zagrebu, Filozofski fakultet, Odsjek za sociologiju, Hrvatska e-mail: ttrako@ffzg.hr}

SAŽETAK Cilj je rada empirijski utvrditi iskustvo života u ruralnim područjima i rada u poljoprivredi mladih obiteljskih poljoprivrednih gospodarstvenika (OPG-ovaca) u dvije hrvatske županije, Bjelovarsko-bilogorskoj i Požeško-slavonskoj. U teorijskom dijelu rada konceptualizira se suvremeni socioekonomski kontekst kvalitete života u hrvatskim ruralnim područjima i poljoprivredi kao zanimanju, s posebnim naglaskom na mladima kao ključnim nositeljima ruralnog razvoja, koje se želi privući da u tim područjima ostanu. Operacionalizacijom odabranih objektivnih i subjektivnih aspekata kvalitete života oblikovano je kvalitativno istraživanje, koje je provedeno metodom polustrukturiranih intervjua $s$ deset sugovornika, mladih poljoprivrednika OPG-ovaca Bjelovarsko-bilogorske i Požeško-slavonske županije, dviju susjednih poljoprivredno snažnih županija sjeverne Hrvatske, jedne s većim, a druge s manjim brojem stanovnika. Protokolom intervjua ispitane su prednosti i nedostaci te prepreke i izazovi s kojima se suočavaju mladi poljoprivrednici, kao i samoprocjena zadovoljstva ruralnim življenjem te percepcija budućnosti.

Sugovornici su kao pozitivne strane života u ruralnim područjima naveli vlasništvo nad kućom, zemljom i dvorištem, svjež zrak, prirodu, tišinu, mir, zdrav život i slobodu, dok su kao ključnu negativnu stranu istaknuli lošu infrastrukturnu opremljenost. Pozitivne su strane bavljenja poljoprivredom rad za sebe, rad „od kuće“, sigurnost posla, samostalno određivanje radnog vremena, svestranost zanimanja, mogućnost razvoja i napretka te zdrav okoliš, dok su negativne strane nepopularnost tog zanimanja, nedostatak vremena, ovisnost o vremenskim uvjetima, velik opseg posla, nestabilnost cijena te s tim povezana nesigurnost poljoprivredne proizvodnje. Kao najveće prepreke bavljenju poljoprivredom koje percipiraju mladi OPG-ovci u ovom istraživanju pokazale su se administrativne prepreke, nedostatak zemljišta te korupcija i „pogodovanje moćnijima“.

Ključne riječi: ruralna područja, mladi poljoprivrednici, Bjelovarsko-bilogorska županija, Požeško-slavonska županija, kvaliteta života, zadovoljstvo životom. 


\section{Uvod ${ }^{1}$}

U analizama transformacija koje u suvremenosti proživljavaju ruralna područja najčešće se ističu snažni izazovi, koji uključuju globalizacijske pritiske, probleme nepovoljne i nekonkurentne pozicije na slobodnom tržištu, potrebu za modernizacijom i tehnološkim napretkom s jedne strane, ali i očuvanjem identiteta i prilagodbom modernizacijskih procesa vlastitom tempu i sadržaju razvoja s druge strane, kao i dugogodišnje zanemarivanje ruralnih prostora i njihovog stanovništva u razvojnim politikama.

Ni Hrvatsku nisu zaobišla šira globalna kretanja globalizacije, industrijalizacije i urbanizacije te prodor novih komunikacijskih tehnologija i tehnoloških inovacija. Istovremeno, hrvatska su se ruralna područja, posebice nakon druge i treće modernizacije, morala suočiti i sa sebi svojstvenim izazovima. Kako objašnjavaju Petak, Puljiz i Štambuk (2002.:235), nakon agrarne reforme te raspada agrarnog društva i tradicionalne seoske strukture, pod jakim utjecajem industrijalizacije, sloma zadrugarstva i kolektivizacije poljoprivrede (1950-ih godina), dolazi do specijalizacije i individualizacije poljoprivrednih gospodarstava, deagrarizacije, promjena u demografskoj situaciji, ali i integracije seljaštva u globalni društveni sustav, suvremene tehnologije i inovacije (1960-ih). Petak i sur. (2002.:235-236) dalje navode kako ruralni prostor pod utjecajem urbanizacije i industrijalizacije uspostavlja novu ravnotežu s gradom, te se javlja sve više mješovitih domaćinstva i seljaka-radnika (1970-e i 1980-e godine), a potom i moderna obiteljska poljoprivredna gospodarstva, te prodiru novi oblici poduzetništva i javljaju se novi načini korištenja ruralnih prostora (krajem 1980-ih i početkom 1990-ih). Međutim, ratno i poslijeratno razdoblje ostavilo je teške posljedice u smislu demografije te potrebe za materijalnom obnovom infrastrukture i okoliša (Petak i sur., 2002.:236; vidjeti i: Petak, 2000.:6-7). Konačno, socijalne i ekonomske prilike koje su pratile demokratizaciju i liberalizaciju hrvatskog društva kroz posljednjih 30 godina od njenog osamostaljenja, kao i ulazak Hrvatske u Europsku uniju (EU) 2013. godine, koji je zahtijevao usklađivanje strateških ciljeva s europskim politikama, također su se odrazili na uvijek osjetljivija ruralna područja.

Ključni čimbenik otpornosti ruralnih područja na navedene globalne i lokalne pritiske svakako je ruralno stanovništvo, $\mathrm{i}$ to prije svega mlado radno sposobno reproduktivno stanovništvo. No, upravo se kontingent tog stanovništva u tim područjima smanjuje snažnim iseljavanjem mladih, koji pretežito iz ekonomskih i obrazovnih razloga većinom odlaze u gradove, u kojima najčešće i ostaju živjeti. Stoga dolazi do pada nataliteta i senilizacije ruralnog stanovništva, ali i s time povezane deagrarizacije, kao i općenito

${ }^{1}$ Rad je nastao na temelju diplomskog rada Helene Pupak „Iskustva mladih obiteljskih poljoprivrednih gospodarstvenika (OPG-ovaca) u Bjelovarsko-bilogorskoj i Požeško-slavonskoj županiji“, pod mentorstvom doc. dr. sc. Tijane Trako Poljak, obranjenog 2020. godine na Odsjeku za sociologiju Filozofskog fakulteta u Zagrebu. 
deruralizacije. U Hrvatskoj se, kako prenose Nejašmić i Toskić (2016.:195), od 1971. do 2011. godine broj stanovnika neurbanih naselja smanjio za gotovo $20 \%$ (prema: Nejašmić i Štambuk, 2003.:474), odnosno udio seoskog stanovništva u ukupnom stanovništvu smanjio se s $39,6 \%$ 2001. na 38,4\% 2011. godine. Sve se to odrazilo i na poljoprivredu, koja bilježi kontinuiran pad postotka zaposlenih. Prema posljednjem Popisu stanovništva iz 2011. godine u Hrvatskoj je bilo 5,31\% ukupnog stanovništva zaposlenog u sektoru poljoprivrede, šumarstva i ribarstva (Državni zavod za statistiku [DZS], 2011.), a 2018. godine taj je broj iznosio 1,9\% (DZS, 2019.).

U europskim razvojnim strategijama ruralna se područja sve više prepoznaju kao važna mjesta za očuvanje prirodnih bogatstava, koja su sve ugroženija zbog globalne socijalno-ekološke krize, za zaštitu kulturne raznolikosti, ali i bolju kvalitetu života, pri čemu se, primjerice, zdraviji život sporijeg tempa suprotstavlja onom urbanom. Poseban se naglasak stavlja na ruralne mlade kao nositelje strategija ruralnog razvoja, pri čemu je nužno poboljšati njihovu kvalitetu života kako bi privlačni čimbenici nadvladali potisne. Otkad je Hrvatska postala punopravnom članicom EU-a, njene strategije također ukazuju na važnost održivog regionalnog razvoja, s posebnim naglaskom na motiviranje mladih na ostanak u zemlji (Vlada Republike Hrvatske, 2017.:25). U Programu ruralnog razvoja mladi su također prepoznati kao ključni resurs, uključujući i u održavanju modernog i konkurentnog poljoprivrednog sektora (Ministarstvo poljoprivrede, 2018.:125). Poljoprivredni fondovi EU-a omogućuju ulaganja u modernizaciju te povećanje učinkovitosti i kvalitete poljoprivredne proizvodnje, kao i širenje poljoprivrednih i nepoljoprivrednih aktivnosti i poslovanja u ruralnim područjima. Nedavna pandemija bolesti COVID-19 dodatno je ukazala na važnost lokalne poljoprivredne proizvodnje po principu „od farme do stola“ te osvijestila ulogu ruralnih područja i poljoprivredne proizvodnje u opskrbi zdravom hranom kao i u nacionalnoj prehrambenoj sigurnosti.

Međutim, neki od glavnih negativnih čimbenika koji utječu na smanjenje kvalitete života, a time i želju ruralnih mladih da ostanu i rade u ruralnim područjima, su nezaposlenost, otežan pristup obrazovanju i usavršavanju, prepreke pri uspostavljanju novih poduzeća te manjak temeljne infrastrukture i usluga (European Network for Rural Development, 2018.:1). Slične probleme prepoznaju i domaća istraživanja provedena među ruralnim mladima (Žutinić i sur., 2010.; Žutinić i Bokan, 2008.; Šundalić, 2006.; Stipić, 2018.; Kuzmić, 2020.; Babić i Lajić, 2001.).

U tom smislu ovaj rad teži empirijski istražiti iskustvo života u ruralnim područjima i rada u poljoprivredi mladih obiteljskih poljoprivrednih gospodarstvenika (OPG-ovaca) u dvije hrvatske županije, Bjelovarsko-bilogorskoj i Požeško-slavonskoj. Provedeno je kvalitativno istraživanje metodom dubinskih polustrukturiranih intervjua s deset mladih poljoprivrednika u dvije hrvatske županije, Bjelovarsko-bilogorskoj i Požeško-slavonskoj. Bjelovarsko-bilogorska i Požeško-slavonska županija odabrane su jer 
zbog bogatstva prirodnih resursa, mnoštva ruralnih naselja te njihove umreženosti $s$ razvijenijim gradskim naseljima posjeduju velik potencijal za kvalitetu života i rada u ruralnim područjima, posebice mladih ljudi i obitelji. Protokolom intervjua kojim su ispitani o prednostima i nedostacima te preprekama i izazovima s kojima se kao mladi poljoprivrednici suočavaju obuhvaćeni su odabrani objektivni aspekti kvalitete života u ruralnim područjima i rada u poljoprivredi, subjektivni aspekt samoprocjene zadovoljstva ruralnim življenjem te percepcija budućnosti. Uz vrijedne iznimke, domaćoj znanstvenoj literaturi nedostaje novijih empirijskih podataka na temelju kojih bismo mogli dublje razumjeti motivaciju mladog ruralnog stanovništva da ostanu ili se vrate u ruralna područja te bave poljoprivrednom djelatnošću. Posljednja sustavna istraživanja koja su se bavila područjem ruralnosti u Hrvatskoj objavljena su prije deset i više godina, što ne implicira da je ova tema sociološki irelevantna, već je pokazatelj mnogih drugih procesa koji su se zbivali kako na globalnoj razini tako i u Hrvatskoj. Međutim, relevantnost je ove teme i danas višestruka jer, kako kaže Štambuk (2002.:364), ,ondje gdje selo nije razvijeno, ne može se govoriti o razvijenosti“ ili, kako tvrdi Župančić (2002.:36): „Iako značaj poljoprivrede opada s općim razvojem [...], njezin značaj za ruralni prostor ipak ne opada razmjerno tome. To posebno vrijedi za krizne prilike u društvu". Stoga se nadamo da će i ovo skromno istraživanje pomoći doprinijeti razumijevanju kvalitete života i rada mladih poljoprivrednika u te dvije županije, kako bi se utvrdila ključna mjesta na koja treba djelovati da bi se pomoglo njihovu unaprjeđenju.

\section{Teorijski okvir}

\subsection{Kvaliteta života mladih u ruralnim područjima}

Kvaliteta života širok je pojam koji obuhvaća različite dimenzije i pokazatelje, ovisno o nizu čimbenika, kao što su odabrani teorijski okvir, metodologija istraživanja, vrsta i dostupnost podataka, te cilju i području istraživanja. Međutim, većina se autora danas slaže da se radi o višedimenzionalnom pojmu koji u sebi obuhvaća objektivne i subjektivne pokazatelje. Eurostat tako kvalitetu života mjeri kao „skup statističkih pokazatelja koji uzimaju u obzir objektivne čimbenike (kao što su prihod, stambeni uvjeti, radni status itd.) te subjektivne procjene tih čimbenika, što dovodi do različitih razina zadovoljstva, ovisno o prioritetima i potrebama pojedinaca" (DZS, 2021.). Neki autori razgraničavaju pojmove kvalitete života, zadovoljstva životom i dobrobiti (za raspravu o tome vidjeti npr.: Vukadin i sur., 2016.), dok ih drugi koriste kao sinonime, a treći kao višerazinske pojmove. U ovom se radu oslanjamo na Cumminsa (1996.; 2000.), pa se kao krovni pojam uzima kvaliteta života, koja obuhvaća objektivne komponente kvalitete života i subjektivnu komponentu zadovoljstva životom. U tom smislu, „zadovoljstvo je subjektivna kategorija na koju mogu ali ne moraju djelovati objektivne okolnosti“" (Seferagić, 1990.:154). 
Kako bismo odabrali pokazatelje kvalitete ruralnog življenja i bavljenja poljoprivredom za ovo istraživanje, oslonili smo se na postojeća domaća istraživanja koja ukazuju na relevantne privlačne i potisne čimbenike za ruralne mlade (za sažeti pregled vidjeti: Popović, Relja i Gutović, 2017.:71-94). Njihovi su rezultati uglavnom komplementarni te prije svega ukazuju na to da su najčešće poteškoće za mlade u ruralnim područjima vezane za zaposlenje i slabu infrastrukturnu opremljenost. Kod problema vezanih za zaposlenje javljaju se loši uvjeti rada u poljoprivredi, manjak prilika za zaposlenje u nepoljoprivrednim zanimanjima, otežana uspostava vlastitih poslovnih prilika i otežan pristup edukaciji (Žutinić i sur., 2010:152; Žutinić i Bokan, 2008.:150; Šundalić, 2006:141; Stipić, 2018.:35). Slaba infrastrukturna opremljenost odnosi se prije svega na prometnu izoliranost te manjak sociokulturnih sadržaja (Žutinić i Bokan, 2008.:151; Šundalić, 2006:141; Babić i Lajić, 2001.:79). Gotovo identične ukupne rezultate pokazuje i nedavno istraživanje Kuzmić (2020.:45).

Ne moramo posebno isticati da manjak prilika za zaposlenje u poljoprivredi i nepoljoprivrednim zanimanjima kao i poteškoće pri otvaranju vlastitih poduzeća imaju izravan utjecaj ne samo na želju već i na samu mogućnost ostanka mladih u ruralnim područjima i kvalitetnu financijsku skrb o sebi i svojoj obitelji. Uz to, vezano za poljoprivredna zanimanja, mladi upozoravaju na loše uvjete rada te se, kako ističe Šundalić (2006.:141), javlja „zapostavljanje i neprofitabilnost do jučer dominirajuće djelatnosti“. Također, za mlade je poljoprivrednike posebno važno i posjedovanje temeljnog resursa za poljoprivrednu proizvodnju, na što je još ukazao Martić 1971. godine, kada je ustvrdio da je poljoprivrednicima vrlo bitan vlastiti zemljišni posjed na kojemu se može obavljati poljoprivredna djelatnost, a prema kojem imaju i poseban odnos (Martić, 1971.).

Infrastruktura je također izuzetno važna, a podrazumijeva "tehničku opremljenost koja je preduvjet za uspješno funkcioniranje raznovrsnih službi i naselja kao cjeline“ (Štambuk i Mišetić, 2002.:157). Nažalost, hrvatska ruralna naselja većinom karakterizira skromna infrastrukturna opremljenost (Župančić, 2005.; Svirčić Gotovac, 2006.; Štambuk i Mišetić, 2002.). Istraživanje koje je Župančić proveo 2005. godine ukazuje na loše stanje u kojem „samo manji broj ruralnih naselja ima važnije ustanove, poštanski ured, dok je malo povoljnije stanje s uslužnim radionicama, komunalnom opremljenošću, sportskim objektima" (Župančić, 2005.:651). Još je 2002. godine, kako Župančić sažima istraživanje Štambuk i Mišetić, utvrđeno da „osnovnu školu ima samo $27 \%$ sela, zdravstvenu ambulantu tek $11,5 \%$ sela, stomatološku ambulantu $6,5 \%$ naselja, a $12 \%$ seoskih naselja poštanski ured“, $s$ velikim regionalnim razlikama (Štambuk i Mišetić, 2002.:155-177, u: Župančić, 2005.:651).

Župančićevo (2005.:617) istraživanje nadalje je utvrdilo da se u ruralnim naseljima kojima nedostaju elementarne službe i institucije stanovništvo moralo koristiti takvim uslugama u većim lokalnim središtima i gradovima. Mreža naselja stoga je od velikog 
značaja, a definira se kao „sistem naselja u kome postoje funkcionalne, socijalne i druge veze među naseljima“" (Seferagić, 1987.:70). Drugim riječima, mreža naselja omogućuje da stanovnici infrastrukturno manje opremljenih naselja svoje potrebe zadovolje u obližnjim bolje opremljenim naseljima. Međutim, kvaliteta života i unutar mreže naselja Hrvatske pokazala se kao nezadovoljavajuća, pri čemu su podaci za ruralna naselja i njihove lokalne centre najlošija (Svirčić Gotovac, 2006.:121).

Sve se to nužno odražava i na druge aspekte koji su posebice bitni ruralnim mladima, kao što su način provođenja slobodnog vremena te sadržaji koji se za to nude. Tako su obrasci provođenja slobodnog vremena već desetljećima slični, uz gotovo neprimjetne promjene. Istraživanje provedeno 1990. godine pokazalo je da „deprivilegiranost mladih seljaka u korištenju vlastitog provođenja slobodnog vremena ponajviše proizlazi iz nametnutog ograničenja nedostatne kulturne ponude u seoskim sredinama" (Ilišin, 1990.:295). Mlado stanovništvo iskazalo je nezadovoljstvo takvim nedostatkom, pri čemu „značajnu ulogu igraju i narasle aspiracije jer se i razina obrazovanja mladih poljoprivrednika povećala i jer su sredstva masovnog komuniciranja impregnirala seosku svakidašnjicu mnogim urbanima fenomenima" (Ilišin, 1990.:303). Zanimljivo je i istraživanje prema kojem ,u slučaju načina provođenja slobodnog vremena razlike su veće između pojedinih kategorija seoskog stanovništva nego između sela i grada", što pokazuje „da u selu već sada postoje grupacije koje imaju sasvim 'urbanizirani' način provođenja slobodnog vremena, grupacije koje svojim načinom života transformiraju selo i osiguravaju njegovu modernizaciju i reprodukciju" (Hodžić, 2002.:93).

Konačno, uz navedene objektivne pokazatelje, za procjenu kvalitete života svakako je važan i subjektivni aspekt zadovoljstva životom. Sugovornici u ovom istraživanju izravno su pitani jesu li zadovoljni životom u ruralnim područjima te što im se posebno sviđa, a što bi izdvojili kao loše strane ruralnog življenja. Također, pitani su i da sami procijene vlastiti društveni položaj poljoprivrednika, na čiju važnost ukazuju rana istraživanja (Martić, 1988.), a potvrđuju i kasnija, pa tako, primjerice, o problemu dvostruke stigmatizacije ruralnog stanovništva kao seljaka i radnika govori Štambuk (2014.:72), a o osjećaju socijalne isključenosti ruralnih mladih od ostatka društva Žutinić i Bokan (2008.:157.).

Uzimajući u obzir navedene objektivne i subjektivne pokazatelje kvalitete života u ruralnim područjima na koja ukazuju postojeća istraživanja u Hrvatskoj, operacionalizirali smo kroz protokol polustrukturiranog intervjua sljedeće dimenzije: iskustvo života na selu, pri čemu su postavljena pitanja o zadovoljstvu životom u ruralnim područjima te infrastrukturi (prometnoj, komunalnoj i komunikacijskoj), dostupnosti zdravstvene i socijalne skrbi, obrazovnih institucija, financijskih službi, uslužnih djelatnosti te pitanja o slobodnom vremenu i načinu korištenja slobodnog vremena; iskustvo rada u poljoprivredi, pri čemu su postavljena pitanja o zanimanju poljoprivrednika, organizacijskoj strukturi OPG-ova, proizvodnji, prodaji, komunikaciji, financijama te o stanju 
poljoprivrede u hrvatskom društvu te planovi za budućnost, pri čemu su sugovornici pitani za mišljenje o perspektivi života u ruralnim područjima i radu u poljoprivredi unutar sljedećih deset godina, o namjeri proširenja OPG-a te bi li taj način života i rada preporučili budućim naraštajima.

\subsection{Obiteljska poljoprivredna gospodarstva}

Značenje poljoprivrede za hrvatsko gospodarstvo, usprkos tome što je bila najznačajnija privredna djelatnost na početku dvadesetog stoljeća te bila ključna za rast proizvodnje, sve je manje (Stipetić, 2005.:25). Suvremenu poljoprivrednu djelatnost u Hrvatskoj čine pretežito obiteljska poljoprivredna gospodarstva (OPG-ovi), koja se definiraju kao „organizacijski oblik gospodarskog subjekta poljoprivrednika fizičke osobe koji radi stvaranja dohotka samostalno i trajno obavlja djelatnosti poljoprivrede i s njom povezane dopunske djelatnosti, a temelji se na korištenju vlastitih i/ili unajmljenih proizvodnih resursa te na radu znanju i vještinama članova obitelji“ (Zakon o obiteljskom poljoprivrednom gospodarstvu, NN 29/18). U 2017. godini zabilježeno je ukupno 165.167 registriranih OPG-ova (Agrobiz, 2017.), dok ih je 2019. godine zabilježeno ukupno 154.679 (Agencija za plaćanja u poljoprivredi, ribarstvu i ruralnom razvoju, 2020.).

Temeljni problem s kojim se hrvatska poljoprivreda danas suočava jest senilizacija, odnosno starenje stanovništva, koje se posebno očituje u poljoprivrednoj djelatnosti - gotovo pola od ukupnog broja nositelja OPG-ova iz 2017. godine imalo je više od 60 godina (Agrobiz, 2017.). Tako se i trend smanjenja ukupnog broja OPG-ova uporno nastavlja, a može se smatrati posljedicom negativnih demografskih kretanja, kao i s time povezanih procesa deruralizacije i deagrarizacije, odnosno napuštanja ruralnih područja i poljoprivrede. Osim OPG-ova, unutar kojih se članovi obitelji bave isključivo poljoprivrednom djelatnošću, danas su važna i mješovita gospodarstva, koje određuju „izvori primanja i zanimanje (aktivnost) članova obitelji u nepoljoprivrednim djelatnostima, tj. činjenica da se u kućanstvu osim poljoprivrede stječe dohodak i izvan poljoprivrede" (Cifrić, 2003.:357). No, usprkos tim negativnim trendovima, kao i činjenici da su globalizacija, industrijalizacija i tehnološki napredak omogućili zapošljavanje i izvan primarnih djelatnosti, poljoprivreda je i dalje temeljna djelatnost ruralnih područja.

Razvoj ruralnih područja stoga se pretežito temelji na vitalnim gospodarstvima i poduzetnom ruralnom stanovništvu, pri čemu su od iznimne važnosti upravo mladi poljoprivrednici. Pojam „mladi poljoprivrednik“ relativno je noviji i kao takav se koristi u strateškim planovima razvitka ruralnog područja i objašnjenjima raznih potpora koje su im namijenjene. Mladi je poljoprivrednik osoba starija od 18, a mlađa od 40 godina na dan podnošenja Zahtjeva za potporu, pri čemu mora imati određena stručna znanja te mora po prvi put biti nositelj obiteljskog poljoprivrednog gospodarstva 
(Agroklub, 2016.). U prilog problematici senilizacije ide podatak da se „poljoprivrednici mlađi od 40 godina nalaze na čelu samo $11 \%$ svih poljoprivrednih gospodarstava u Europskoj uniji“ (Europska komisija, 2020.), stoga je glavni cilj i izazov mnogih strategija poljoprivrednog i ruralnog razvoja motivirati upravo tu skupinu na poljoprivrednu djelatnost, ali i život u ruralnim područjima. Iako Dilić još 1977. godine, dakle prije više od četrdeset godina, opaža da mlade motivira ili bavljenje poljoprivredom od rane životne dobi ili ih na to usmjerava jednostavno nedostatak izbora, i danas bi se to moglo smatrati relevantnim.

Osim OPG-ova i mješovitih gospodarstava, važno je istaknuti i poljoprivredne zadruge kao još jedan oblik organizacije u poljoprivrednoj djelatnosti u Hrvatskoj. Zadruga se definira kao „dobrovoljno, otvoreno, samostalno i neovisno društvo kojim upravljaju njezini članovi, a svojim radom i drugim aktivnostima ili korišstenjem njezinih usluga, na temelju zajedništva i uzajamne pomoći ostvaruju, unapređuju i zaštićuju svoje pojedinačne i zajedničke gospodarske, ekonomske, socijalne, obrazovne, kulturne i druge potrebe i interese i ostvaruju ciljeve zbog kojih je zadruga osnovana" (Zakon o zadrugama, NN 34/11).

\subsection{Požeško-slavonska i Bjelovarsko-bilogorska županija}

Požeško-slavonska županija, $s$ površinom od $1.815 \mathrm{~km}^{2}$ i ukupnim brojem od 78.034 stanovnika, nalazi se na sjeveroistoku Republike Hrvatske, a graniči sa Sisačko-moslavačkom, Bjelovarsko-bilogorskom, Virovitičko-podravskom i Osječko-baranjskom županijom (Regionalna razvojna agencija PSŽ-PANORA, 2018.:10). U prijašnjim Popisima stanovništva bilježi pad ukupnog broja stanovništva, što predstavlja ključnu slabost za razvoj njenih naselja, posebice ruralnih. Ukupno poljoprivredno zemljište te županije u odnosu na ukupnu poljoprivrednu površinu Republike Hrvatske iznosi $2,79 \%$, što i nije začuđujuće $s$ obzirom na ukupnu površinu cijele županije, koja je po veličini petnaesta u usporedbi s ostalim županijama. Požeško-slavonska županija nailazi na sljedeće razvojne probleme: „neadekvatna povezanost lokalnih prometnica s glavnim pravcima, nezadovoljavajuće stanje kolnika županijskih i lokalnih prometnica te stanje tehničkih elemenata županijskih i lokalnih prometnica, nedostatak biciklističke infrastrukture, neodgovarajući uvjeti pješačkog prometna i nedostatak nogostupa, neadekvatan javni prijevoz putnika, neiskorištenost željezničkog transporta, neadekvatno održavanje željezničke infrastrukture te nedovoljna pokrivenost dijela županije širokopojasnom infrastrukturom" (Regionalna razvojna agencija PSŽ-PANORA, 2018.:161).

Bjelovarsko-bilogorska županija dvostruko je veća od Požeško-slavonske, a prostire se na površini od 2.636,67 km², s ukupnim brojem od 133.084 stanovnika. Graniči s Koprivničko-križevačkom, Virovitičko-podravskom, Požeško-slavonskom, Sisačkomoslavačkom te Zagrebačkom županijom (Regionalna razvojna agencija Bjelovarsko- 
bilogorske županije, 2010.:14). Ustrojena je kao pet gradova i osamnaest općina, a sjedište joj se nalazi u gradu Bjelovaru. Poljoprivredne površine zauzimaju 51,2\% površine te županije, koja kao i Požeško-slavonska posjeduje potencijal za daljnji razvoj gospodarstva upravo na poljoprivrednoj djelatnosti. U 2018. godini Bjelovarskobilogorska županija bila je jedina u Hrvatskoj koja je 20\% svog BDP-a ostvarivala iz poljoprivrede, a među prvim je županijama i po broju prijavljenih i realiziranih ugovora za program Ruralnog razvoja (Bjelovarsko-bilogorska županija, 2018.).

\section{Metodologija}

Kvalitativno sociološko istraživanje provedeno je metodom polustrukturiranog intervjua od sredine lipnja do sredine srpnja 2020. godine, a ukupno je provedeno deset intervjua s mladim poljoprivrednicima OPG-ovcima koji žive i rade u ruralnim područjima Bjelovarsko-bilogorske i Požeško-slavonske županije.

Uzorak je prigodni, a ključni kriteriji za sudjelovanje u istraživanju bili su mjesto stanovanja (ruralno naselje unutar Bjelovarsko-bilogorske ili Požeško-slavonske županije), mlađa dob (od 18 do 40 godina) te zanimanje (poljoprivrednik - nositelj OPG-a). Pet sugovornika bilo je iz Bjelovarsko-bilogorske županije (područje grada Garešnice i općine Dežanovac), a pet iz Požeško-slavonske županije (područje grada Lipika). Također, pet se sugovornika bavi isključivo poljoprivredom, dok se pet bavi poljoprivredom kao dodatnim zanimanjem uz zaposlenje izvan poljoprivredne djelatnosti, što se definira kao mješovito poljoprivredno gospodarstvo. Sugovornici koji su sudjelovali u istraživanju u dobi su od najmanje 22 i najviše 39 godina.

Istraživanje je započelo kontaktiranjem pet poznanika, nakon čega se metodom snježne grude došlo do ostalih sugovornika, te su intervjui provođeni do zasićenja podataka. Prije provedbe intervjua svakom sugovorniku uručena su po dva primjerka teksta informiranog pristanka, a jamčena im je anonimnost u predstavljanju rezultata istraživanja. Svi intervjui provedeni su licem u lice, bez prisustva treće osobe te uz pridržavanje tadašnjih mjera propisanih od Stožera civilne zaštite Republike Hrvatske zbog pandemije bolesti COVID-19. Istraživanje je provela prva autorica ovog rada za potrebe diplomskog rada. Istraživanje je dobilo potrebnu potvrdu Povjerenstva Odsjeka za sociologiju za prosudbu etičnosti istraživanja Filozofskog fakulteta u Zagrebu (23-2019/20, 10. lipnja 2020.). Tijekom intervjua vođene su bilješke, kako bi analiza i interpretacija intervjua mogle biti što preciznije i validnije. Nakon transkripcije intervjua, kodiranje i tematska analiza izvršene su pomoću računalnog programa za kvalitativna istraživanja MAXQDA.

Svi sugovornici odgovarali su na ista pitanja, pri čemu su postavljana i dodatna potpitanja ovisno o odgovorima sugovornika. Protokol polustrukturiranog intervjua sadržavao je četiri tematske cjeline. Prvi set pitanja nazvan je Uvodna pitanja, a odnosio se na 
sociodemografske karakteristike sugovornika - mjesto stanovanja, dob, najviši završeni stupanj obrazovanja te zanimanje. Drugi set pitanja nazvan je Iskustvo života na selu (Zadovoljstvo životom na selu), a u njemu su se nalazila pitanja o tome jesu li zadovoljni životom u ruralnom području (što bi izdvojili kao prednosti i nedostatke), zatim pitanja o infrastrukturi (prometnoj, komunalnoj i komunikacijskoj), dostupnosti zdravstvene i socijalne skrbi, obrazovnih institucija, financijskih službi, uslužnih djelatnosti te pitanja o slobodnom vremenu te načinu i prilikama korištenja slobodnog vremena. Treći se set pitanja ticao Iskustva rada u poljoprivredi, a u njemu su se nalazila pitanja o zanimanju poljoprivrednika, infrastrukturi i proizvodnji, prodaji i komunikaciji, financijama te o poljoprivredi u hrvatskom društvu. Posljednji, četvrti set pitanja nazvan je Planovi za budućnost, a u njemu su se nalazila pitanja o planovima unutar sljedećih deset godina po pitanju života u ruralnim područjima i radu u poljoprivredi, o namjerama proširenja OPG-a i o preporukama za buduće naraštaje.

\section{Rezultati istraživanja}

\subsection{Kvaliteta života u ruralnim područjima}

Kvaliteta života u ruralnim područjima ispitana je putem pitanja o osobnoj procjeni zadovoljstva ruralnim životom, prednostima i nedostacima ruralnog življenja te kroz pitanja o infrastrukturnoj opremljenosti te načinu i prilikama provođenja slobodnog vremena.

\section{Zadovoljstvo ruralnim životom}

Kao pozitivne strane življenja u ruralnim područjima sugovornici su istaknuli vlasništvo nad kućom, zemljom i dvorištem, svjež zrak, prirodu, tišinu, mir, zdrav život i slobodu.

[...] zato što čovjek puno vremena provodi u prirodi, na, na mirnom je mjestu, nije u, neka buka, galama i tak', nije jako prometno puno, ono, miran je život uglavnom eto, to je prva prednost, najveća. (Sugovornik 5, 23)

Svida mi se to, što ja kažem, kad ja odem, eto, u polje, u njivu, imam svoj mir i tišinu, ovaj, unatoč tom svom poslu, čovjek nekako nade neku svoju zadovoljštinu, ovaj, što kažu - moje je, moje je. Ja ne volim buku, galamu i ovaj, e to ti je - mir, tišina. Dobro, tišina, kad radiš sa strojevima nije tišina, al' nekako ti je to, znaš da radiš ono što voliš $i$ to te eto, na neki način, ispunjava. (Sugovornik 7, 39)

Kao negativne strane sugovornici su istaknuli lošu prometnu infrastrukturu, odnosno nedostatak javnog prijevoza. U tom kontekstu uspoređivali su ruralna i urbana naselja 
te posebno isticali kako je život u ruralnim naseljima u mnogočemu skuplji od onoga u gradskim, što je vrlo zanimljivo zapažanje koje ide protiv opće percepcije o cijeni života u ruralnim područjima.

\section{U manjim mjestima nema tol'ko akcije, popusta i nečega. (Sugovornica 6, 27)}

Skuplje je jednostavno zato što kad si na selu, što god ti treba, bez auta ne možeš zamislit' život, znači, ti uvijek moraš ić' u nekakav prvi grad, prvu veću općinu, a to sve košta, znači, opskrbljivanje hranom, opskrbljivanje bilo čim ti veže troškove, troškove. Briga o djeci, znači, sve jednostavno puno zamornije i iscrpljujuće i zahtijeva puno veći angažman. (Sugovornik 8, 22)

Svi su sugovornici na izravno pitanje o zadovoljstvu materijalnom situacijom i životnim standardom odgovorili da su zadovoljni.

\section{Infrastrukturna opremljenost}

Sugovornicima su postavljana dodatna pitanja o sljedećim elementima infrastrukturne opremljenosti: prometnoj, komunalnoj i komunikacijskoj infrastrukturi, zdravstvenim uslugama, socijalnoj skrbi, obrazovnim institucijama, financijskim službama te uslužnim djelatnostima. Uz to im je postavljeno i potpitanje o tome što smatraju da od navedenog nedostaje ili da bi trebali imati u svom naselju.

Povezanost sa susjednim naseljima svi su sugovornici opisali kao dobru, ističući da im se ostala naselja nalaze relativno blizu te da u njima mogu zadovoljiti svoje osnovne potrebe. Međutim, posebno su istaknuli tri problema: prvi je problem uređenja i održavanja cestovnih i poljskih puteva, drugi je problem lošeg javnog prijevoza te, povezano s tim, nužnost posjedovanja osobnog automobila i vozačke dozvole. Svi sugovornici navode kako u njihovim naseljima postoji javni prijevoz (autobusni ili željeznički), no i da je on nerijetko namijenjen prije svega učenicima. Dakle, redovni javni prijevoz ponegdje je nepostojeći, a taj se učenički odvija dva puta dnevno, dok ga preko ljetnih školskih praznika uopće nema. Nužnost posjedovanja osobnog automobila, bez kojega ne bi bilo moguće živjeti u ruralnim područjima, problem je koji posebno pogađa maloljetnike te starije i nemoćne osobe.

Jedino što zamjerka je da su poljski putevi užasno loši, da se slabo održavaju, da se ulaže u njih kod općina i tak', gradova. (Sugovornik 5, 23)

Nažalost, konkretno u mom selu ne. Što se tiče, recimo, $i$ djece za školu $i$ tako autobus prode jedanput do dva puta na dan $i$ to je to. Znači, ova ostala djeca koja idu u srednju, to je za osnovnu školu pričamo, ovi koji idu u srednju školu, oni se čak moraju sami, dobar dio ili roditelji vozit' ili nešto, znači, nemaju osiguran javni prijevoz, recimo, do najbliže srednje škole, a to bi bila [grad], je l'. (Sugovornik 10, 32) 
Ne, ovdje nema nikakvih... ustvari, ima, ima jedna linija ujutro i u podne se vrati autobus i to je sve što se tiče linija, je l'. Znači ovdje ne možemo živjet' bez auta, nikako. (Sugovornik 1, 38)

[...] tko nema auto, ti roditelji su $u$ dosta velikim problemima. [...] nema ni vlaka, kažem, samo autobus koji prode ujutro i pokupi, je l', djecu i popodne, recimo... (Sugovornik 10, 32)

Komunalna i komunikacijska infrastruktura u ruralnim je naseljima nešto skromnija nego u urbanim. Od deset sugovornika tek je dvoje reklo kako imaju provedenu kanalizaciju, vodovod njih sedmero, dok električnu energiju, redoviti odvoz otpada, javnu rasvjetu i Internet imaju svi sugovornici. Međutim, jedan sugovornik ističe problem redovite opskrbe električnom energijom, a sugovornici kao probleme navode i uslugu Interneta, posebice sporost mreže.

Od deset sugovornika tek je jedan sugovornik rekao kako imaju dom zdravlja i ljekarnu, ali ne i hitnu pomoć. Ostali sugovornici zdravstvene usluge mogu dobiti u mjestu udaljenom deset i više kilometara, gdje im se nalaze dom zdravlja, ljekarna i hitna pomoć. I u tom slučaju ističu nedostatak javnog prijevoza kao ključni problem za one koji ne posjeduju prijevozno sredstvo. Mnoge zdravstvene usluge nije moguće dobiti ni u tim centrima (općinama i većim gradovima), stoga su primorani odlaziti u još veća naselja, koja su udaljena 30 i više kilometara, što, naravno, iziskuje dodatne troškove prijevoza.

Znači, hitna i bolnica [nema u selu] $i$ eto jedino što imamo našu doktoricu i ljekarna je odma’ preko puta pa u slučaju za neke antibiotike ili nešto ne mora se ići daleko, može se obavit', eto, u istom mjestu. [...] Pa trenutno ne jer nismo tol'ko jako udaljeni, imamo nekih deset-petnaest minuta autom [do hitne] pa nije to tol'ki problem, al'opet ne'ko 'ko nema prijevoza, opet je taj javni prijevoz, eto, problem. (Sugovornica 6, 27)

Zatim su postavljena pitanja vezana za socijalnu skrb, dom za starije i nemoćne, jaslice i vrtiće za djecu. Jedan sugovornik u svom ruralnom naselju ima dom za starije i nemoćne, dok ostali nemaju. Drugi sugovornik ima vrtić za djecu, dok ostali nemaju ništa od navedenog, pa se tim uslugama koriste u drugim naseljima u kojima su dostupne.

Od obrazovnih institucija osnovnu školu imaju tek dva sugovornika, dok se srednja škola ne nalazi ni u jednom naselju. Osnovna škola u jednom naselju funkcionira na način da se učenici u njoj obrazuju do četvrtog razreda, nakon čega moraju putovati u veći grad ili drugo naselje javnim prijevozom. U drugoj osnovnoj školi učenici se obrazuju od prvog do osmog razreda. 
Pa srednja škola je isto dovoljno dost' udaljena, javnog prijevoza pošto nema, učenici su prisiljeni biti u domu ili otic' znači iz svog mjesta u neki drugi grad, tako da srednja škola bi isto mogla bit jer ima dovoljno prostora kod nas. (Sugovornica 6, 27)

Od uslužnih djelatnosti svi imaju trgovinu mješovite robe, u kojoj nabavljaju osnovne namirnice, dok za sve ostalo što se ondje ne može kupiti odlaze u veće gradove. Poljoprivredne trgovine i apoteke nema nitko, za čime su neki od njih izrazili potrebu.

Financijske službe još su jedan bitan element zadovoljstva životom. Sugovornike se pitalo postoje li u njihovom ruralnom naselju pošta, osiguravajuća društva, banke i bankomati. Jedan je sugovornik naveo kako nema potrebu za financijskim službama jer je javni prijevoz u njegovom naselju dovoljno dobar. Svi ostali sugovornici istaknuli su potrebu za poštom i/ili bankomatom u svom naselju. Iako se mnogi od njih koriste Internetom za vođenje financija, smatraju kako bi trebalo uvesti mnoge elemente osnovne financijske infrastrukture.

Zanimljivo je da nekoliko sugovornika zaključuje da ne postoji potreba za uvođenjem ili osuvremenjivanjem dijelova infrastrukture jer je brojčano sve manje stanovnika ruralnih područja, posebice mlađih, kojima bi to koristilo.

\subsection{Način provođenja slobodnog vremena}

Sugovornicima je izravno postavljeno pitanje o načinu provođenja dokolice te dostupnosti sadržaja - kulturnih, zabavnih i sportskih.

Mladi poljoprivrednici, s obzirom na prirodu zanimanja kojim se bave, slobodno vrijeme vežu uz zimski period jer tada imaju manji opseg posla nego tijekom ostatka godine. Slobodno vrijeme provode odlaskom u kafiće, kino ili na bazene, bavljenjem sportskim aktivnostima, druženjem s prijateljima, kolegama ili obitelji, odmaranjem te korišstenjem Interneta i društvenih mreža. Ističu da nema mnogo događaja tijekom godine na kojima bi se moglo provesti slobodno vrijeme, osim nekih koji se odvijaju jednom godišnje. Međutim, navode i da se nalaze u relativnoj blizini gradova u koje mogu otići u kino, kafić, klub, na bazen, koncert, zabavu i tako dalje.

Ne mogu ja fantazirat'o tom da bi mi još nešto trebali radit’ i da bi zajednica trebala investirat' u taj kraj, jednostavno tu nema 'ko to ni koristit nit' to ima ni 'ko gradit. Jer mladih nema. (Sugovornik 8, 22)

Zanimljivo je da se ponovno javlja tema lošeg demografskog stanja, pa na izravno pitanje imaju li potrebe za više događaja i aktivnosti odgovaraju negativno, a kao razlog navode manjak broja mladih ljudi koji bi te sadržaje upražnjavali. 


\subsection{Iskustvo rada u poljoprivredi}

Iskustvo rada u poljoprivredi istraženo je kroz pitanja o motivaciji za poljoprivrednu djelatnost, načinu stjecanja znanja o poljoprivredi, upravljanju OPG-ovima (poljoprivrednoj infrastrukturi i proizvodnji, prodaji proizvoda i suradnji s kupcima, otkupljivačima i zadrugama, financijskom vođenju OPG-a) te percepciji zanimanja poljoprivrednika. Sugovornici se bave isključivo ratarstvom. Prema kriteriju veličine poljoprivredne površine (Odak, 2017.:32), u ovom istraživanju sudjelovali su nositelji pet malih OPG-ova (obrađuje se od 2 do 20 hektara), tri srednja (od 20 do 100 hektara) i dva velika (više od 100 hektara, u našem istraživanju do 250 hektara).

\section{Motivacija za bavljenje poljoprivredom}

Glavna je motivacija za bavljenje poljoprivredom kod sugovornika činjenica da su u tom poslu „od malih nogu“", zatim obitelj, ljubav prema tom poslu i dodatna zarada. Devet je sugovornika istaknulo kako se tim zanimanjem bave od najranije dobi te da su posao naslijedili od svojih očeva, dok se tek jedan sugovornik $s$ mješovitog gospodarstva $s$ tim poslom susreo po prvi put te je jedini naveo dodatnu zaradu kao motivaciju. Navedenih devet sugovornika naveli su i da su razvili ljubav prema poslu, što ih je dodatno motiviralo da se time nastave baviti.

[...] svi koji su me poznali su znali da sam ja zaluden s tim i da je meni sam' to, to, to, $i$ da mi je to, ono, život. I jednostavno to baš, ono, od malih nogu, ljubav i strast koja se javila i koja ti je zvanje i kad je nest', nešto nečije zvanje, tim' se treba bavit' jer tu ćeš bit’ najbolji, to voliš. (Sugovornik 8, 22)

Rad „od malih nogu“ za većinu je sugovornika bio i način na koji su stjecali iskustvo rada u poljoprivrednoj djelatnosti, i to uz pomoć roditelja, pretežito očeva, ali i prijatelja, poznanika i agronomskih stručnjaka. Od deset sugovornika koji se bave tim zanimanjem jedna je osoba visokoobrazovana sa završenim diplomskim studijem ekonomskog usmjerenja, dok je još jedna osoba u procesu obrazovanja te završava preddiplomski studij agronomskog usmjerenja i planira nastaviti obrazovanje na diplomskom studiju. Ostalih osam sugovornika sa srednjom stručnom spremom dio formalnog obrazovanja o poljoprivrednoj djelatnosti stekli su putem kratkih tečajeva i edukacija koje se održavaju na lokalnoj razini, a koji su ujedno i preduvjet za ostvarivanje određenih prava na poticaj za mlade poljoprivrednike.

\section{Proizvodnja, promocija i prodaja poljoprivrednih proizvoda}

Kako bi se uopće mogli baviti poljoprivrednom djelatnošću, mladim je poljoprivrednicima potreban osnovni proizvodni resurs, a to je zemlja. Upravo nedostatak i ne- 
dostupnost zemljišta, kao i njegovu cijenu za zakup, sugovornici navode kao iznimno veliku prepreku za daljnji razvoj svojih OPG-ova.

[...] za zemljište često puta teško dobit’ i kredit jer ti trebaš dobit’ kredit, a ne, a zemlja ti je... znači, zemljište je osnovni infrastrukturni, znači, osnovna sirovina, osnova da bi ti mog'o nešto dalje gradit' $i$ radit' nekakvu priču $i$ analitiku $i$ analizu $i$ kakvu ćeś ti proizvodnju imat' i šta ćeš ulagat' i šta ćeš radit' - bez zemljišta ne možeš ništa. A kad ti dođeš bez ičega u banku s tim - s idejom da bi ti tražio kredit za zemljište na kojem ti onda trebaš kupit' sve, znači, od repromaterijala, objekata, strojeva, znači, da ti nemaš, ne znam, to je jednostavno... jako teško je nekom mladom s idejom, s voljom, sa obrazovanjem, svejedno doć' do ikakvih novaca jer nemaš pokrića. Šta ćeš dat', ak' nemaš zemlju, oke, ideš kupovat' zemlju, daš zemlju pod hipoteku, imaš, dao si zemlju, radis, tu si i tak' dalje. (Sugovornik 8, 22)

Unutar ovog seta pitanja, kojim se istražuje prodaja proizvoda, komunikacija s kupcima, otkupljivačima i zadrugama, svi sugovornici zadovoljni su mogućnostima prodaje svojih proizvoda. Tako, primjerice, ističu da za prodaju imaju veći broj silosa kojima voze svoje poljoprivredne proizvode, što znači da ih prodaju na domaćem tržištu, no također kazuju da nisu upoznati s time gdje u konačnici završi njihov proizvod. Temeljni problemi s kojima se susreću vezani su i uz nestabilnost cijene, odnosno uz problem tržišta i otkupa.

Uspijeva sve dobro, ali je cijena uvijek loša. Nikad se ne zna cijena. Kad se proizvede $i$ kad se proda, onda se tak zna cijena, nema cijene kad se posadi, kao u drugim državama. Njemačka, Austrija, Slovenija, oni znaju cijene čim idu sadit’ nešto, a mi kod nas nemamo te cijene. (Sugovornik 2, 33)

Sedam sugovornika svoje proizvode prodaje otkupljivačima, s kojima neki od sugovornika imaju ugovore, što im osigurava prodaju. Jedan sugovornik ističe kako im se kupci javljaju i sami, ali iz intervjua se može zaključiti kako se u tom slučaju radi o velikom i izrazito razvijenom OPG-u, koji posluje na području cijele Hrvatske, uključujući i poslovanje s globalnim trgovačkim lancima. Tek jedan od sugovornika, nositelj velikog razvijenog OPG-a, koristi agencije i reklame kako bi prezentirao svoje proizvode i tako privukao kupce. Mladi poljoprivrednici informiraju se o mogućnostima prodaje pretežito u komunikaciji s kolegama, prijateljima, susjedima i onima koji se također bave tim poslom.

Što se tiče suradnje sa zadrugama, četiri sugovornika nisu upoznata sa zadrugama i njihovim načinom funkcioniranja, dok ostali sugovornici imaju podijeljena mišljenja. Jedan sugovornik ističe njihovu nepotrebnost, dok ostalih pet ističe pozitivne strane poljoprivrednih zadruga, ali i probleme poljoprivrednog zadrugarstva u Hrvatskoj. Posebno se izdvaja jedan pozitivan stav sugovornika spram poljoprivrednih zadruga, prema kojemu one u Hrvatskoj ne mogu opstati: 
Zadruge da, ali u Hrvatskoj ne. [...] Jednostavno kod nas mora se dogodit generacijska izmjena u nositeljima poljoprivrednih gospodarstva jer postojeći nositelji nema šanse da zadruge uspijevaju, ili jako mali broj. Znači kod nas je jednostavno problem - mi ne možemo [uzdah]... naš balkanski mentalitet uvjetuje sto drugih stvari. Mladi i moja generacija ja se nadam da će bit', da će imat' taj doseg i tu mogućnost da se riješi tih nekih malo primitivnih, glupih barijera 'ja moram bit' najpametniji, ja moram bit' najbolji, meni sve mora bit prvo" da shvatimo da to treba gledat' i kroz brojke, da je ekonomski zdravo gledano, zdravo logički gledano da je zadruga - to su čisti novci za nas sve. [...] I onda svu godišnju dobit oni, znači, ta zadruga ostvaruje dobit koju kod nas ostvaruje sve ne'ko drugi, a ne poljoprivredni proizvodači, tu dobit onda, $u$ biti, odlućuju u kojoj strukturi budu - dio se ostavlja za ulaganje, za dalje obnovu, povećanje i tak' dalje, a dio si isplaćuju kao čistu dobit svakom članu zadruge. I to je predobar sistem jer na taj način poljoprivreda ide dva koraka unaprijed i, normalno, brži je obrtaj novca, brže ćemo se razvit', ali kod nas zbog mentaliteta zadruge... ima par pokušaja, par su i propali, par su i završili, malverzacija u kojekakvim stvarima, jednostavno jako teško, jako teško do udruživanja i da poljoprivredni proizvodači shvate da je to dobro zapravo dobra stvar jer to nije strašno. I da zaśto ne bi nas dvadeset il' pedeset s ovog područja kupilo, napravilo silos, otplatilo ga za tri il' pet godina, kroz dugoročni kredit $i$ dalje zaradivalo novce, skladistilo svoju robu, sebi duže, prodalo dio... [...] e kad bi to zaživilo, kod nas bi onda za pet godina već naša poljoprivreda bila na nekim drugim granama, ali realno gledajući ne bude tak' skoro [smijeh]. (Sugovornik 8, 22)

\section{Financijsko upravljanje OPG-om}

Financije OPG-a, uključujući brigu o prihodima i rashodima, osiguranju, vođenju svih potrebnih papira i dokumentacije, sugovornici vode samostalno ili kroz knjigovodstvene servise. Godišnji troškovi u poljoprivrednoj djelatnosti ukazuju na promjenu i napredak poljoprivrede. Tehnološke inovacije, potreba za povećanjem proizvodnje, osiguranje usjeva, vozila i sl. javljaju se kao bitne stavke koje zahtijevaju redovita i dodatna ulaganja u poljoprivrednoj proizvodnji. Iznos prosječnih godišnjih troškova mladih poljoprivrednika varira ovisno o veličini OPG-a. Tako, primjerice, sugovornik koji obrađuje dva hektara na svom OPG-u prosječno godišnje financijski izdvaja oko 3.000 kuna, dok onaj koji radi na OPG-u veličine dvjesto i pedeset hektara izdvaja oko 500.000 kuna.

U okviru ulaska Hrvatske u EU, koja je omogućila poboljšanje proizvodnje uvođenjem EU fondova, poljoprivrednici su općenito dobili određenu financijsku sigurnost, pogotovo ako se u obzir uzmu prethodno spomenute nestabilne cijene, kao i nestabilnost tržišta. Svi sugovornici koriste državne poticaje, dok tek neki koriste one za mlade poljoprivrednike. Oni koji ih ne koriste ističu kako su se pokušavali prijavljivati na natječaje, no nisu na njima prošli, a objašnjenje nisu dobili. Nužno angažiranje 
stručne osobe koja se bavi pisanjem i vođenjem takvih projekata predstavlja problem, kao i nedostupnost nekih fondova, posebno europskih, čije uvjete mali primarni poljoprivrednici koji se bave isključivo poljoprivredom smatraju da ne mogu ispuniti.

Pa dosta loše jer, kao, potiču mlade da imaju poljoprivredu i da se bave, da ostaju u državi, al'onda kad se javite na neke natječaje il' nešto za mlade poljoprivrednike, nema dovoljno jer, kao, ovi stariji imaju višse godina ugovore ili nešto, onda njima na osnovu toga produžuju, a mi mladi ne možemo doć” do toga ak' smo otvorili OPG nedavno. (Sugovornica 6, 27)

O poticajima se informiraju putem Interneta, preko poljoprivrednih agencija, poznanika i kolega. Upotreba Interneta i komuniciranje s agencijama putem e-maila, kako ističu neki od sugovornika, još je jedan od bitnih i novijih elemenata u suvremenoj poljoprivredi.

\section{Pozitivne i negativne strane bavljenja poljoprivredom}

Pozitivne su strane bavljenja poljoprivredom rad za sebe, rad „od kuće“, sigurnost posla, samostalno određivanje radnog vremena, svestranost zanimanja, mogućnost razvoja i napretka, zdrava okolina te naposljetku ljubav prema tom poslu.

Pa, na primjer, k’o prvo, sto sam sam sebi gazda, mislim, sam sebi planiram dan, raspored, kako da kažem i tak pos'o organiziram i to, imam pa većinu, dost' i slobodnog vremena i u sezoni kad je posla, onda ima posla, al' uglavnom eto, to je jedna od najpozitivnijih stvari što si sam svoj gazda, ajmo reć. (Sugovornik 5, 23)

Kao negativne strane bavljenja poljoprivredom sugovornici ističu nepopularnost tog zanimanja, administrativne prepreke, korupciju i „pogodovanje moćnijima“, ovisnost o vremenskim uvjetima, velik opseg posla, nestabilnost cijena i nesigurnost povezanu s cijenama te nedostatak vremena.

Negativne strane bavljenja poljoprivredom su, govorim u današnje vrijeme, iz perspektive nas mladih, sta često puta poljoprivreda nije uopće popularno zanimanje i smatra se kao prljav posao, kao da je to, ajmo reć, dosta, iako generalno, mišljenje o poljoprivredi je da je poljoprivreda motika. [...] al' cesto puta zbog tih nekomunikacija sustava i svega skupa mladi ne iskoriste - kol'ki dečki, prijatelji, kolege su mogli iskoristit' neke prilike, nisu zato jer nije ništa jasno rečeno - nigdje nije ništa jasno prezentirano $i$ to je ogroman problem. (Sugovornik 8, 22)

Zanimljivo je da je nekoliko sugovornika vrlo oštro kritiziralo poticaje, pri čemu su isticali potrebu za njihovim ukidanjem ili smanjenjem. Nekolicina sugovornika istaknula je potrebu za uvođenjem tržišnih cijena koje neće oscilirati do te mjere da poljoprivrednike svaku godinu ili sezonu ostavljaju u određenoj neizvjesnosti. 
Poljoprivreda je danas nešto petnaest puta drugačije od motike i davno je prestala bit’ motika jer vrijeme i razvoj novih implementacija i tehnologija u poljoprivredi-od snimanja $i$ mapiranja parcela sa dronom, sa strojevima koji u žetvi, sjetvi mjere prinos, mjere stanje tla i tak dalje - poljoprivreda je otišla doslovce u digitalno doba, jako velikim i brzim iskoracima. Mi tu na obiteljskom poljoprivredom gospodarstvu kod kuće dosta dobro i pratimo i strojevi koje imamo imaju SIM kartice, šalju podatke o navodnjavanju, jednostavno to, to je danas postala poljoprivreda dva nula ili pametna poljoprivreda, koja uključuje brojne softvere, aplikacije, koja, gotovo nijedan našstroj ne radi bez navigacije, sve je GPS, RTK signali, postavljeno gdje je to otišlo u ogromnom smjeru naprijed. A generalno mišljenje je da je poljoprivreda motika i to je često puta, ajmo reć, podrugljivo, uvijek kao primitivno i glupo zanimanje i ti si bezveze sto to radiš i sto si ti na polju i zemlji i šta ti je to, šta ti je to. (Sugovornik 8, 22)

\section{Percepcija zanimanja poljoprivrednika}

Odnos je hrvatskog društva prema poljoprivrednicima, kako ga doživljavaju sami poljoprivrednici, negativan - smatraju kako u društvu nisu cijenjeni, a kao glavni razlog navode poticaje. Za negativnu percepciju poljoprivrednog zanimanja u društvu jedan sugovornik smatra odgovornima društvo, ali i same poljoprivrednike.

[...] i sami poljoprivrednici rade jednu veliku grešku... o čemu se radi - radi se, znači, o tome - on ima veliku površinu i sve to stoji, ali poljoprivrednici ne moraju vozit džipove i, ne znam ni ja, uzimat' neke skupe automobile, što mi, što hrpa ljudi radi. To meni k'o poljoprivredniku isto nije, nije mi jasno... vozilo ti treba, normalno, sve to stoji, ali ne treba ti sad džip za dvjesto tisuća kuna ili ne znam ni ja šta, ovaj, znači, s time sami, s tim činom rade lošu sliku prema svim poljoprivrednicima [...] i onda stvaraju jako lošu sliku o svim poljoprivrednicima. E to, to mi se ne svida. (Sugovornik 7,39 )

\subsection{Perspektive budućnosti}

U okviru ove teme sugovornicima je postavljeno pitanje gdje se vide za deset godina smatraju li da će i tada živjeti u ruralnom području i baviti se poljoprivredom te bi li preporučili poljoprivredno zanimanje svojoj djeci ili mlađim generacijama.

Svi su sugovornici istaknuli kako planiraju ostati živjeti u ruralnom području i baviti se poljoprivredom. Devet sugovornika odgovorilo je kako planira proširivati svoj OPG - neki od njih planiraju proširivati kupovinom zemljišta, dok nekoliko njih planira povećati svoje OPG-ove u smislu proizvodnje nekih novih poljoprivrednih kultura. Očekivano, nositelj najvećeg OPG-a odgovorio je kako trenutno teško stiže obavljati sve s obzirom na opseg posla, zbog čega ne planira dalje proširivati OPG. 
Svi sugovornici preporučuju ruralni život mlađim generacijama ili svojoj djeci. Smatraju da taj način života nosi više prednosti u usporedbi sa životom u gradu, posebice po pitanju dugoročnog zdravlja i kvalitete života. Također ističu kako je takav život bolji neovisno o izboru zanimanja.

Naravno da bi, život na selu je najbolji, najbolji mogući je život na selu, život u ovim našim provincijama, kad ti znaš, kad krenem iz [sela], znam da sam za dve i pol-tri minute u centru [grada]. A kad ti u Zagrebu sjediš četrdeset pet minuta u gužvi, sjediš prvi put, sjediš drugi put, sjediš stoti put u životu, e dode ti da stvarno nikad više ne dodeš u Zagreb. Jednostavno k'o prvo to - okolis, zdravlje, odgajanje djece, prostor, pogledi, krajolik, zdravstvena ispravnost, sve oko tebe, voda, šta god hoćeš, jednostavno život na selu je, po meni, je skuplji, sigurno je skuplji nego život u gradu, ali dugoročno je bolji i ja mislim da je to svakome ljep̌si život u konačnici neg’u nekakvom stančiću. (Sugovornik 8, 22)

Međutim, po pitanju preporuke poljoprivrednog zanimanja mlađim generacijama ili djeci u obitelji sugovornici su podijeljenih mišljenja - šest sugovornika bi preporučilo, dok četiri sugovornika ne bi preporučila bavljenje poljoprivrednim zanimanjem. Oni koji bi mladima preporučili bavljenje poljoprivrednim zanimanjem ponovno ističu pozitivne strane života u ruralnim područjima, u ovom slučaju povezane is radom $u$ poljoprivredi - rad u prirodi, samostalno određivanje radnog vremena, svestranost poljoprivrede i mogućnosti napretka. U tom kontekstu ističu kako bi njihovoj djeci kao nasljednicima OPG-a i zemljišta bilo puno lakše nego nekome tko kreće bez ikakvih resursa. Oni koji ne bi preporučili to zanimanje smatraju kako bi mladima bilo bolje da se visoko obrazuju i zaposle negdje gdje imaju određeno radno vrijeme te stabilnu i sigurnu plaću.

\section{Zaključak}

Cilj je ovog rada bio empirijski utvrditi iskustvo života u ruralnim područjima i rada u poljoprivredi mladih obiteljskih poljoprivrednih gospodarstvenika (OPG-ovaca) u dvije hrvatske županije, Bjelovarsko-bilogorskoj i Požeško-slavonskoj. Provedeno je kvalitativno istraživanje metodom polustrukturiranih intervjua, tijekom kojih su sugovornici govorili o prednostima i nedostacima te preprekama i izazovima s kojima se kao mladi poljoprivrednici suočavaju, zadovoljstvu životom u ruralnim područjima i bavljenjem poljoprivrednom djelatnošću te percepciji budućnosti.

Istraživanjem je utvrđeno kako su sugovornici generalno zadovoljni ruralnim životom te životnim standardom i vlastitom materijalnom situacijom. Mladi poljoprivrednici kao pozitivne strane života u ruralnim područjima ističu osobno vlasništvo nad kućom, zemljom i dvorištem, svjež zrak, prirodu, mir i tišinu te zdrav život i slobodu koju im takav život donosi. Slobodno vrijeme, kada ga imaju, provode odlaskom u 
kafiće, kino ili na bazene, u bavljenju sportskim aktivnostima, druženju s prijateljima, kolegama ili obitelji te odmaranju.

Međutim, sugovornici ističu i negativne strane života u ruralnim područjima, a to je prije svega slaba infrastrukturna opremljenost. Takvi rezultati u skladu su s rezultatima ranijih istraživanja, kojima se utvrdila slaba infrastrukturna opremljenost ruralnih naselja, s time da nekima nedostaju elementarne službe i institucije, posebice zdravstvene i obrazovne ustanove (Župančić, 2005.; Štambuk i Mišetić, 2002.). Ti su rezultati u skladu s postojećim istraživanjima o ruralnim mladima, koja su također ukazivala na problem infrastrukturne neopremljenosti (Kuzmić, 2020.:45; Žutinić i Bokan, 2008.:151; Šundalić, 2006:141; Babić i Lajić, 2001.:79). Izravna posljedica infrastrukturne neopremljenosti nužnost je korištenja takvih usluga u većim i bolje opremljenim obližnjim ruralnim ili gradskim naseljima. Međutim, problem predstavlja i loša prometna infrastruktura, uključujući i loš javni prijevoz, zbog čega je sugovornicima život nezamisliv bez posjedovanja osobnog automobila, a posebno je u tom smislu izazovan za maloljetnike te starije i nemoćne osobe. Naime, gotovo svakodnevno postoje određene obveze koje iziskuju putovanje - odlazak liječniku, plaćanje računa, kupovina namirnica, obrazovanje i sl. Nadalje, sugovornici spominju sporu internetsku vezu kao još jedan infrastrukturni problem, s obzirom na to da Internet danas predstavlja glavni izvor informiranja i važno sredstvo komunikacije. Mladi poljoprivrednici navode da ga koriste u svrhu informiranja o novostima u poljoprivredi, kao i za komunikaciju prilikom prijavljivanja na razne projekte i natječaje koji su im nužni za napredak u poljoprivrednoj djelatnosti. Zanimljivo je da neki sugovornici napominju kako ni u svojem ni u obližnjim ruralnim naseljima nemaju dostupnu mesnicu, što ukazuje ne samo na manjak te važne uslužne djelatnosti već i na promjene u načinu života i rada u hrvatskim ruralnim područjima. Tradicionalno je gotovo svako domaćinstvo imalo dovoljno prehrambenih proizvoda (mesa, voća i povrća) za zadovoljenje svojih potreba pa i više. Međutim, danas je stanovnicima ruralnih područja postalo neisplativo hraniti domaće životinje isključivo za svoje potrebe, posebice $s$ obzirom na mnogo povoljnije cijene tih proizvoda (kvaliteta je nešto drugo) i njihovu trajnu dostupnost na tržišstu.

Što se tiče bavljenja poljoprivredom, prema sugovornicima, pozitivne su strane rad za sebe, rad „od kuće“, sigurnost posla, samostalno određivanje radnog vremena, svestranost zanimanja, mogućnost razvoja i napretka te zdrava okolina. Na poljoprivrednu djelatnost motiviralo ih je bavljenje tim poslom „od malih nogu“, obitelj, ljubav prema tom poslu i mogućnost dodatne zarade. Dodatnu zaradu kao motivaciju za bavljenje poljoprivredom posebno su isticali oni koji rade na mješovitim poljoprivrednim gospodarstvima.

Negativne su strane tog posla nepopularnost zanimanja, nedostatak vremena, ovisnost o vremenskim uvjetima, velik opseg posla, nestabilnost cijena te $s$ tim povezana ne- 
sigurnost poljoprivredne proizvodnje. Pritom su kao najveće prepreke bavljenju poljoprivredom isticali administrativne prepreke s kojima se kao poljoprivrednici suočavaju, manjak zemljišta, ali i korupciju i „pogodovanje moćnijima“, što su spominjali kod, primjerice, prijavljivanja na natječaje za europske i druge fondove. Problemi nedostatka i previsokih cijena zakupa zemljišta, posebice državnog zemljišta, nisu samo problemi za te individualne slučajeve, već pogađaju širu populaciju poljoprivrednih djelatnika i onih koji se za tu djelatnost obrazuju. Kako možemo očekivati razvoj ruralnih područja na temelju poljoprivredne djelatnosti, koja je još uvijek dominantno zanimanje u tim područjima, ako se posebice mladima ne pruži mogućnost da dođu do osnovnog resursa - zemlje? Problemi manjka zemlje ukazuju na to da će poljoprivredno zanimanje još dugo vremena biti obiteljsko zanimanje koje se nasljeđuje generacijama, odnosno zanimanje prvenstveno namijenjeno onima koji već žive u ruralnim područjima i koji su s poljoprivredom već upoznati. Nadalje, kako svoje proizvode ne prodaju izravno, već otkupljivačima po cijenama koje im se ponude, javlja se nekonkurentnost malih poljoprivrednih proizvođača.

Konačno, kada su govorili o percepciji zanimanja poljoprivrednika, iako oni sami svoje zanimanje percipiraju vrlo pozitivno, smatraju da u širem društvu nisu cijenjeni te odnos hrvatskog društva prema poljoprivrednicima doživljavaju negativnim. Kao jedan od razloga navode i medije, koji, po njima, nedovoljno izvještavaju o poljoprivredi i poljoprivrednicima, a nerijetko o njima izvještavaju i u negativnom svjetlu dobivanja financijskih poticaja i naknada.

Današnje stanje ruralnih područja i poljoprivrede u Hrvatskoj nužno je preokrenuti, a sami stanovnici tih područja daju vrijedne podatke o svojoj percepciji smjera i sadržaja tih promjena. Primjerice, rezultati upućuju na značaj mreže naselja. Svih deset ruralnih naselja u kojima žive sugovornici dobro je umreženo, što omogućuje zadovoljenje osnovnih potreba njihovih stanovnika, koje bi zbog infrastrukturne neopremljenosti bilo teško samostalno ispuniti. Promjene u načinu življenja i provođenju dokolice ukazuju na nove potrebe mladog ruralnog stanovništva, koje je potrebno imati na umu pri planiranju modernih programa i politika ruralnog razvoja koje će biti u toku $s$ vremenom. Pojavila se i tema značaja zadrugarstva kao potencijalnog rješenja koje bi poljoprivrednicima omogućilo zajedničko obavljanje poljoprivredne djelatnosti unutar organizacije koja bi osiguravala proizvodnju, poljoprivredno zemljište i resurse, ali i pomagala u vidu mnogih teškoća i prepreka s kojima se trenutno suočavaju. Osim toga, poljoprivredno zadrugarstvo sa sobom nosi jednostavniji pristup tržištu, što posljedično dovodi do povećanja konkurentnosti i omogućavanja intenzivnijeg razvoja (Agrobiz, 2020.). U prilog potencijalu poljoprivrednih zadruga u Hrvatskoj govorila su i druga domaća istraživanja (Božić, Šprajc i Srbljinović, 2019.). Ono što također može motivirati mlade ljude koji imaju interes za poljoprivrednu djelatnost jesu bolje zakonske regulative o raspolaganju državnim poljoprivrednim zemljištem, bolji zakonski okviri o poticajima kao i mladima primjereniji uvjeti na natječajima 
za poticaje i zaposlenje u poljoprivredi. U razvojnim strategijama svakako treba staviti još veći naglasak na ruralne mlade i mlade poljoprivrednike, pa tako trebaju biti u samom središtu Strategije ruralnog razvoja Republike Hrvatske, Strategije razvoja poljoprivrede i ribarstva Republike Hrvatske te Nacionalne strategije poljoprivrede i ruralnog razvoja. Naravno, bez općeg poboljšanja uvjeta življenja, kao i uvjeta rada u poljoprivrednoj djelatnosti, teško možemo očekivati revitalizaciju hrvatskih ruralnih područja i ostanak ili povratak mladih koji bi se odlučili za život i rad u njima.

Na kraju je potrebno istaknuti nekoliko ograničenja ovog i preporuke za buduća istraživanja. Zbog prigodnosti uzorka ovog kvalitativnog istraživanja, prvo je ograničenje nemogućnost generaliziranja dobivenih podataka na cijelu populaciju mladih poljoprivrednika u Republici Hrvatskoj. Drugo, sugovornici u ovom istraživanju bavili su se isključivo ratarstvom, pa se tako ovdje nisu mogla čuti iskustva mladih poljoprivrednika iz nekih drugih poljoprivrednih područja. Isto tako, svi sugovornici dolaze s područja dvaju gradova i jedne općine u dvije županije, pa ne postoji raspršenost uzorka, što je na kraju i dovelo do toga da je broj od deset sugovornika u istraživanju bio dovoljan za postizanje zasićenosti, odnosno donošenje zaključaka na temelju dobivenih podataka. Međutim, nadamo se da će i ovo istraživanje doprinijeti postojećim i potaknuti buduća istraživanja o ovoj temi, ali i drugim relevantnim temama iz područja ruralne sociologije u Hrvatskoj. Kako bi se moglo kontinuirano i stručno raditi na revitalizaciji ruralnih područja, nasušno nam je potrebno još socioloških i srodnih studija koje bi dale empirijske podatke o različitim aspektima ruralnog razvoja, uključujući i o potrebama ruralnog stanovništva, posebice kroz njihovu vlastitu percepciju izazova s kojima se suočavaju. Sve to pomoglo bi u donošenju pravovaljanih odluka koje mogu doprinijeti njihovoj kvaliteti života i u konačnici učiniti ruralna područja poželjnijim mjestima za život i rad.

\section{Literatura}

1. Agencija za plaćanja u poljoprivredi, ribarstvu i ruralnom razvoju (2020). Upisnik poljoprivrednika. https://www.apprrr.hr/upisnik-poljoprivrednika/. (Pregledano 27. srpnja 2021.)

2. Agrobiz (2017). Fantomski OPG-ovi: Čak 70449 OPG nema niti jednog člana gospodarstva. https://www.agrobiz.hr/agrovijesti/fantomski-opg-ovi-cak70-449-opg-nema-niti-jednog-clana-gospodarstva-5584. (Pregledano 27. srpnja 2021.)

3. Agrobiz (2020). Poljoprivredne zadruge u Hrvatskoj: Dugo gušeni potencijal konkurentnosti. https://www.agrobiz.hr/agrovijesti/poljoprivredne-zadruge-u-hrvatskoj-dugo-guseni-potencijal-konkurentnosti-14763. (Pregledano 27. srpnja 2021.)

4. Agroklub (2016). Tko je točno mladi poljoprivrednik? https://www.agroklub. com/financiranje/tko-je-tocno-mladi-poljoprivrednik/24064/. Pregledano 27. srpnja 2021. 
5. Babić, D. i Lajić, I. (2001). Dilema mladih otočana: ostanak ili odlazak s otoka. Primjer šibenskih otoka. Sociologija sela, 39 (1/4; 151/154): 61-82.

6. Bjelovarsko-bilogorska županija (2018). Pet godina Bjelovarsko-bilogorske županije u Europskoj uniji. Bjelovar: Bjelovarsko-bilogorska županija. https:// bbz.hr/images/uploads/5-godina-bbz-u-eu.pdf. (Pregledano 27. srpnja 2021.)

7. Božić, J.; Šprajc, I. i Srbljinović, A. (2019). Croatian Co-operatives' Story of Revival: Overcoming External Obstacles. Journal of Co-operative Organization and Management, 7 (2). https://www.researchgate.net/publication/336851483 Croatian_Co-operatives'Story_of_Revival_Overcoming_External_Obstacles. (Pregledano 17. prosinca 2020.)

8. Cifrić, I. (2003). Ruralni razvoj i modernizacija. Zagreb: IDIS.

9. Cummins, R. A. (1996). The Domains of Life Satisfaction: An Attempt to Order Chaos. Social Indicators Research, 38: 303-328.

10. Cummins, R. A. (2000). Objective and Subjective Quality of Life: An Interactive Model. Social Indicators Research, 52: 55-72.

11. Dilić, E. (1977). Seoska omladina i poljoprivredno zanimanje, u: Bešker, I. (Ur.). Seoska omladina danas. Zagreb: Centar za sociologiju sela, grada i prostora IDIS-a.

12. Državni zavod za statistiku (2011). Popis stanovništva 2011. Zagreb: Državni zavod za statistiku.

13. Državni zavod za statistiku (2019). Popis stanovništva 2018. Zagreb: Državni zavod za statistiku.

14. Državni zavod za statistiku (2021). Eurostat - Kvaliteta života. Zagreb: Državni zavod za statistiku. https://www.dzs.hr/qol/index hr.html. (Pregledano 27. srpnja 2021.)

15. European Network for Rural Development (2018). Supporting Youth in the EU. An Overview of Policy Investment and Funds. https://enrd.ec.europa.eu/sites/ default/files/ws27 rural-youth policy-instruments-funds.pdf. (Pregledano 27. srpnja 2021.)

16. Europska komisija (2020). Mladi u poljoprivredi. https://ec.europa.eu/info/ food-farming-fisheries/key-policies/common-agricultural-policy/income-support/young-farmers hr\#youngpeopleinfarming. (Pregledano 27. srpnja 2021.)

17. Hodžić, A. (2002). Seoska svakidašnjica, u: Seferagić, D. (Ur.). Selo: izbor ili usud. Zagreb: IDIS.

18. Ilišin, V. (1990). Slobodno vrijeme mladih seljaka. Sociologija i prostor, (109110): 295-304.

19. Kuzmić, T. (2020). Za ili protiv života na selu? (diplomski rad). Filozofski fakultet, Sveučilište u Zagrebu. https://urn.nsk.hr/urn:nbn:hr:131:099598. (Pregledano 27. srpnja 2021.)

20. Martić, M. (1971). Odnos prema zemlji i percepcije statusa i zanimanja poljoprivrednika. Sociologija sela, 9 (4-34): 3-21.

21. Martić, M. (1988). Percepcija društvenog položaja i „zanimanja“ poljoprivrednika. Sociologija sela, 26 (3-4; 101-102): 333-345. 
22. Ministarstvo poljoprivrede (2018). Program ruralnog razvoja Republike Hrvatske za razdoblje 2014.-2020. https://ruralnirazvoj.hr/files/documents/Programruralnog-razvoja-Republike-Hrvatske-za-razdoblje-2014.-2020.-ver.-5.3.pdf. (Pregledano 27. srpnja 2021.)

23. Nejašmić, I. i Štambuk, M. (2003). Demografsko stanje i procesi u neurbanim naseljima Republike Hrvatske. Društvena istraživanja, 12 (3-4): 469-493.

24. Nejašmić, I. i Toskić, A. (2016). Ostarjelost stanovništva seoskih naselja Republike Hrvatske. Migracijske i etničke teme, 32(2): 191-219.

25. Odak, I. (2017). Analiza fragmentiranosti zemljišnih posjeda i primjena rezultata u gospodarenju poljoprivrednim zemljistem (doktorska disertacija). Geodetski fakultet, Sveučilište u Zagrebu. https://www.bib.irb.hr/924442. (Pregledano 27. srpnja 2021.)

26. Petak, A. (2000). Tema dvobroja: hrvatsko selo u tranziciji. Sociologija i prostor, 147/148: 5-9.

27. Petak, A.; Puljiz, V. i Štambuk, M. (2002). Časopis Sociologija sela, razvoj sela i poljoprivrede, razvoj ruralne sociologije. Sociologija i prostor, 40 (3-4; 157-158): 227-251.

28. Popović, T.; Relja, R. i Gutović, T. (2017). Aktualnost ruralne sociologije: problematiziranje održivosti „prostora iza“, u: Bušljeta Tonković, A.; Holjevac, Ž.; Brlić, I. i Šimunić, N. (Ur.). Koga (p)održava održivi razvoj? Prinosi promišljanju održivosti ruralnih područja u Hrvatskoj. Zagreb: Institut društvenih znanosti Ivo Pilar.

29. Regionalna razvojna agencija Bjelovarsko-bilogorske županije (2010). Razvojna strategija Bjelovarsko-bilogorske županije 2011.-2013. Bjelovarsko-bilogorska županija. http://rerabbz.hr/zupanijska-razvojna-strategija/bjelovar/zhupanijska razvojna strategija bjelovarskobilogorske zhupanije. (Pregledano 27. srpnja 2021.)

30. Regionalna razvojna agencija PSŽ-PANORA (2018). Županijska razvojna strategija Požeško-slavonske županije za razdoblje do kraja 2020. godine. Požeškoslavonska županija. https://www.pszupanija.hr/dokumenti/category/150-zupanijska-razvojna-strategija-psz-do-kraja-2020-godine.html. Pregledano 27. srpnja 2021.

31. Seferagić, D. (1987). Mreža naselja u planovima SR Hrvatske, u: Mreža naselja SR Hrvatske. Zagreb: Institut za društvena istraživanja.

32. Seferagić, D. (1990). Razlike u stanovanju između grada i sela, u: Seferagić D. i Milinković, B. (Ur.). Promjene u svakodnevnom životu sela i grada. Zagreb: IDIS.

33. Stipetić, V. (2005). Razvitak poljoprivredne proizvodnje u Hrvatskoj: tendencije, stanje i osnovni problemi. Zbornik radova Ekonomskog fakulteta u Rijeci, 23 (1): 25-50.

34. Stipić, S. (2018). Stavovi i mišljenja mladih o prednostima i nedostacima življenja na selu (diplomski rad). Agronomski fakultet, Sveučilište u Zagrebu. https:// repozitorij.agr.unizg.hr/islandora/object/agr:832. (Pregledano 27. srpnja 2021.) 
35. Svirčić Gotovac, A. (2006). Kvaliteta stanovanja u mreži naselja Hrvatske. Sociologija i prostor, 44 (171/1): 105-126.

36. Štambuk, M. (2002). Selo u europskom iskustvu, u: Štambuk, M.; Rogić, I. i Mišetić, A. (Ur.). Prostor iza: kako modernizacija mijenja hrvatsko selo. Zagreb: Ivo Pilar.

37. Štambuk, M. i Mišetić, A. (2002). Neki elementi socijalne i tehničke infrastrukture hrvatskog sela, u: Štambuk, M.; Rogić, I. i Mišetić, A. (Ur.). Prostor iza: kako modernizacija mijenja hrvatsko selo. Zagreb: Institut društvenih znanosti Ivo Pilar.

38. Štambuk, M. (2014). Lica nigdine. Društveni i prostorni okvir razvitka hrvatskog sela. Zagreb: Institut društvenih znanosti Ivo Pilar.

39. Šundalić, A. (2006). Osiromašivanje i nerazvijenost - Slavonija i Baranja u očima njezinih stanovnika. Socijalna ekologija, 15 (1-2): 125-143.

40. Zakon o obiteljskom poljoprivrednom gospodarstvu, Narodne novine 29 od 2018.

41. Zakon o zadrugama, Narodne novine 34 od 2011.

42. Župančić, M. (2002). Vitalni poljoprivrednici i drugi akteri u razvoju ruralnih područja, u: Seferagić, D. (Ur.). Selo: izbor ili usud. Zagreb: IDIS.

43. Župančić, M. (2005). Infrastrukturna opremljenost hrvatskih seoskih naselja. Sociologija i prostor, 43 (3; 169): 617-657.

44. Žutinić, Đ. i Bokan, N. (2008). Village - Free Choice or Destiny for the Rural Youth (A Study on the Rural Community of Vodinci). Sociologija i prostor, 46 (2; 180): 143-160.

45. Žutinić, Đ.; Kovačić, D.; Grgić, I.; Markovina, J. (2010). Percepcija kvalitete življenja i namjere o odlasku iz ruralnih sredina. Društvena istraživanja, 19 (12): 137-159.

46. Vlada Republike Hrvatske (2017). Strategija regionalnog razvoja Republike Hrvatske za razdoblje do kraja 2020. godine. Zagreb. https://razvoj.gov.hr/o-ministarstvu/djelokrug-1939/regionalni-razvoj/razvojne-strategije/strategija-regionalnoga-razvoja-republike-hrvatske-za-razdoblje-do-kraja-2020-godine/3244. (Pregledano 27. srpnja 2021.)

47. Vukadin, I. K.; Novak, M. i Križan, H. (2016). Zadovoljstvo životom: individualna i obiteljska perspektiva. Kriminologija i socijalna integracija, 24 (1): 84-115. 


\title{
Experiences of Young Farmers on Family-run Farms in Bjelovar-Bilogora and Požega-Slavonia County
}

\author{
Helena Pupak \\ University of Zargreb, Faculty of Humanities and Social Sciences, Department of Sociology, Croatia \\ e-mail: helenapupak@gmail.com \\ Tijana Trako Poljak \\ University of Zargreb, Faculty of Humanities and Social Sciences, Department of Sociology, Croatia \\ e-mail: ttrako@ffzg.hr
}

\begin{abstract}
The aim of this article is to empirically examine the experience of living in rural areas and working in agriculture among young farmers on family-run farms in two Croatian counties: Bjelovar-Bilogora and Požega-Slavonia County. The theoretical part of the paper conceptualizes the contemporary socio-economic context of the quality of life and work in agriculture in Croatian rural areas, with a special emphasis on young people as key drivers of rural development. By operationalizing selected objective and subjective aspects of the quality of life, a qualitative research was conducted using the method of semi-structured interviews with ten young farmers from family-run farms in these two counties. Bjelovar-Bilogora and Požega-Slavonia are two agriculturally strong neighbouring counties in North Croatia, one with higher and one with lower population density. The interviews encompassed questions about the advantages and disadvantages as well as obstacles and challenges faced by young farmers who are living in rural areas and working in agriculture, and their assessment of the satisfaction with rural life and future perspectives.

The interviewees said the advantages of living in rural areas included personal ownership of house and land, fresh air, natural surroundings, peace and quiet, healthy life, and freedom. The disadvantages were mainly seen in poor infrastructure. The positive sides of being employed in agriculture were "being your own boss", "working from home", job security, autonomy in deciding upon your work hours, heterogeneity of different jobs within the occupation, possibility of progress and development, and healthy working environment. The negative sides were lack of popularity of this occupation, lack of time, dependency on external climate factors, large quantity of workload, instability of prices, and uncertainty that comes with this kind of agricultural production. The biggest obstacles for working in agriculture according to young farmers on family-run farms were administrative obstacles, lack of sufficient areas of land, corruption, and nepotism.
\end{abstract}

Key words: rural areas, young farmers, Bjelovar-Bilogora County, Požega-Slavonia County, quality of life, life satisfaction. 